\title{
EFFECT OF IT GOVERNANCE, CONTINUOUS AUDITING AND IT GOALS ALIGNMENT TO COMPANY'S PERFORMANCE (Study on Plantation Companies in the Group of PT. Astra Agro Lestari Tbk in Riau)
}

\author{
NAFISAH SYAFEI \\ Outstanding Lecturer at UIN Suska Riau \\ E-mail : mamalif@gmail.com
}

\begin{abstract}
The purpose of this study is to examine the effect of IT governance, continuous auditing, and the IT goals alignment to company's performance. This study also examined the effect of IT governance to IT goals alignment, the effect of IT governance to continuous auditing, and the effect of IT goals alignment to continuous auditing. Research conducted on the plantation companies in the group of PT. Astra Agro Lestari, Tbk in Riau that have used the information system ERP (Enterprise Resource Planning) to integrate and automate business processes. Population of this study included all managers in these plantation companies. Sampling was conducted by purposive sampling that take samples from the certain level managers who are in the top level of main structure of the six companies in these companies plantation group. Data processing is done to 40 questionnaires returned by respondents using PLS analysis (Partial Least Square). Results of hypothesis testing at the 0.05 significance level indicates that the IT governance, continuous auditing, and the IT goals's alignment affect the company's performance. IT governance affects on the IT goals's alignment and IT governance also affect on the continuous auditing, while the alignment of IT goals has no effect on continuous auditing.
\end{abstract}

Keywords: IT governance, continuous auditing, IT goals alignment, company's performance.

\section{PENDAHULUAN}

Setiap organisasi berusaha untuk mencapai kinerja yang baik. Organisasi dikelola oleh pihak manejemen sebagai perpanjangan tangan pemilik sumber daya ekonomis. Sebagai pihak yang diberi tanggungjawab mengurus penggunaan dan pengendalian sumber daya organisasi (agen) oleh pemilik, manejemen dituntut bertindak untuk mencapai tujuan kepentingan pemilik sumber daya ekonomis tersebut. Kinerja merupakan jawaban dari berhasil atau tidaknya manajemen dalam mengelola perusahaan.

Secara teoritis, ada banyak faktor yang mempengaruhi kinerja perusahaan yang bersumber dari internal maupun eksternal perusahaan seperti strategi bisnis, tatakelola perusahaan, kepemimpinan, teknologi informasi, situasi ekonomi dan politik serta faktor lainnya. Dalam era komunikasi digital, teknologi informasi menjadi faktor penting yang semakin diperhitungkan dalam pencapaian kinerja perusahaan sebagaimana dinyatakan ISACA (2007) bahwa organisasi yang sukses harus memahami manfaat dari teknologi informasi dan menggunakan pengetahuan tersebut untuk mendorong nilai pemegang sahamnya.

Seiring makin berkembangnya teknologi informasi, terlihat fenomena semakin banyaknya perusahaan yang seakan berlomba dalam meningkatkan kecanggihan teknologi informasinya. Hal ini dikarenakan perusahaan menyadari adanya ketergantungan kritis terhadap terhadap teknologi informasi dalam proses bisnisnya, serta adanya kebutuhan untuk memenuhi tuntutan peningkatan kepatuhan terhadap peraturan dan manfaat dari pengelolaan risiko secara efektif (ISACA, 2007).

Teknologi informasi berkaitan dengan segala sesuatu yang berbasis komputer yang digunakan orang untuk 
melakukan pekerjaan yang berhubungan dengan informasi untuk mendukung dan mengolah informasi tersebut sesuai dengan kebutuhan perusahaan (Turban, et al., 2010). Teknologi informasi secara signifikan telah mempengaruhi dan mengubah cara bisnis yang sedang dikelola dan dipantau saat ini (Hunton dan Bagranoff, 2004).

Teknologi informasi menawarkan banyak peluang kepada perusahaan dan organisasi untuk meningkatkan dan mentransformasi produksi, pelayanan, pasar, proses kerja, dan hubunganhubungan bisnis (Henderi, dan Padeli, 2009).

Penerapan teknologi informasi pada suatu sisi menjadi salah satu solusi dalam menghadapi dan memenangkan persaingan seperti dinyatakan Tugas (2010), namun pada sisi lain menurut Henderi, et al (2010), teknologi informasi yang tidak efektif dapat menyebabkan banyak kerugian antara lain pemborosan biaya, melemahkan daya saing, inefisiensi, serta tidak terpenuhinya inovasi dan keuntungan bagi perusahaan.

Perusahaan membutuhkan suatu pengelolaan memadai terhadap teknologi informasi (TI) yang disebut tata kelola TI (IT Governance) untuk menghilangkan kekurangan atau kelemahan serta risiko yang dapat menjadi penghambat kinerja dan inovasi proses dan kegiatan bisnisnya. Tata kelola TI yang baik dibutuhkan dalam suatu organisasi untuk mencapai keunggulan kompetitifnya mengingat salah satu kunci keberhasilan dari perencanaan strategis perusahaan di era modern sekarang adalah memanfaatkan teknologi informasi yang terkelola dan terencana dengan baik (Ulysses, 2013).

Pemrosesan dengan teknologi informasi berdampak terhadap metode yang digunakan untuk memproses transaksi akuntansi, mempengaruhi struktur organisasi perusahaan dan mempengaruhi prosedur dan teknik yang digunakan untuk mencapai tujuan pengendalian internal. Menurut Kayahan
(2013), teknologi informasi secara fundamental mengubah proses akuntansi (pencatatan, penggolongan, pelaporan) dalam bisnis dengan menghapus sumber berdasarkan dokumen berbasis kertas tradisional. Akuntansi yang realtime membutuhkan pengauditan yang realtime untuk memberikan jaminan yang berkelanjutan tentang kualitas dari data tersebut (Martusa et.al, 2011). Audit berbasis realtime menggunakan teknologi informasi sebagai pengganti audit tradisional yang manual dikenal sebagai audit kontinu (continuous auditing).

Teknologi informasi hendaknya diarahkan oleh manejemen untuk memenuhi kebutuhan bisnis perusahaan. Perusahaan terkadang hanya memperhatikan kecanggihan TI yang dimilikinya namun tidak mampu menyelaraskan atau menyesuaikannya dengan kebutuhan bisnis perusahaan seperti yang ditemukan dalam penelitian oleh Marjuki dan Endo (2014). Implementasi TI akan memberikan manfaat yang maksimal ketika adanya keselarasan antara tujuan bisnis dan tujuan TI melalui pengukuran kinerja TI (Tanuwijaya, 2010). Proses penyelarasan menjamin peran serta semua pihak dalam pemanfaatan TI yang efektif bagi perusahaan. Keselarasan merupakan hal yang penting karena mampu mengoptimalkan pemanfaatan TI dalam perusahaan (Tallon, et al., 2000), dan mampu meningkatkan kinerja perusahaan (Cragg, et al., 2002).

Penelitian ini melibatkan manejer tingkat puncak yang bekerja di perusahaan-perusahaan perkebunan PT. Astra Agro Lestari, Tbk di Riau. PT. Astra Agro Lestari, Tbk merupakan perusahaan besar perkebunan yang berkomitmen untuk mengembangkan dan mengadopsi solusi teknologi informasi terkini untuk bersaing meningkatkan efisiensi operasi perseroan (AAL, 2015).

Masih kurangnya penelitian mengenai teknologi informasi, audit yang dilaksanakan dalam era pesatnya kemajuan 
TI, dan bagaimana keselarasan tujuan TI berpengaruh terhadap kinerja perusahaan, dan berdasarkan latar belakang yang telah disajikan maka penulis mengangkat penelitian dengan judul "Pengaruh Tatakelola Teknologi Informasi, Audit Kontinu, Keselarasan Tujuan Teknologi Informasi Terhadap Kinerja Perusahaan (Studi pada Kelompok Perusahaan Perkebunan PT. Astra Agro Lestari, Tbk di Riau)."

\section{HASIL DAN PEMBAHASAN}

a. Teori Keagenan

Teori keagenan mendeskripsikan hubungan antara prinsipal dan agen. Jensen dan Meckling (1976) menjelaskan hubungan keagenan dalam teori agensi (agency theory) bahwa perusahaan merupakan kumpulan kontrak (nexus of contract) antara pemilik sumber daya ekonomis (principal) dan manajer (agent) yang mengurus penggunaan dan pengendalian sumber daya tersebut.

Menurut Messier, et al., (2005) hubungan keagenan ini mengakibatkan dua permasalahan. Masalah pertama yaitu terjadinya informasi yang asimetris (information asymmetry), dimana manajemen secara umum memiliki lebih banyak informasi mengenai posisi keuangan yang sebenarnya dan posisi operasi entitas dari pemilik. Masalah kedua yaitu terjadinya konflik kepentingan (conflict of interest) akibat ketidak samaan tujuan, dimana manajemen tidak selalu bertindak sesuai dengan kepentingan pemilik.

Berkaitan dengan masalah keagenan, tata kelola TI, audit kontinu, dan keselarasan tujuan TI, diharapkan bisa berfungsi sebagai alat untuk mengatasi masalah yang timbul dalam hubungan keagenan dan dapat mewujudkan kinerja perusahaan perusahaan yang lebih baik.

Keunggulan yang paling tampak dari TI adalah kemampuannya menangani transaksi bisnis yang dalam jumlah yang besar dengan efisien (Arens, et al., 2011).
Disamping itu, teknologi informasi menyediakan informasi yang berkualitas tinggi. Aktivitas-aktivitas TI yg kompleks mengharuskan adanya tata kelola TI yang berperan antara lain dalam pengaturan, prosedur dan dokumentasi yang efektif. Hal tersebut menghasilkan informasi yang kualitasnya lebih tinggi serta lebih cepat bagi manejemen perusahaan. Jika manejemen yakin informasi yang dihasilkan oleh TI tersebut dapat diandalkan, manajemen akan menggunakan informasi tersebut untuk keputusan-keputusan manajemen yg lebih baik (Arens, et al., 2011).

Pemantauan secara kontinu dan audit kontinu memberikan manajer dan auditor visibilitas (pandangan) yang lebih tinggi ke dalam proses, kegiatan, dan transaksi (Deloitte, 2010). Visibilitas yang dihasilkan juga menghasilkan transparansi untuk direktur, investor, dan pemangku kepentingan lainnya (Deloitte, 2010). Keselarasan tujuan TI dan bisnis mengarahkan agar tujuan TI sejalan dengan tujuan perusahaan sehingga keselarasan tersebut menjadi pendorong bagi manejemen untuk bertindak sesuai dengan kepentingan perusahan.

\section{Kinerja Perusahaan}

Secara umum kinerja diartikan sebagai keberhasilan dalam mewujudkan sasaran strategi yang telah ditetapkan sebelumnya dengan yang diharapkan (Mulyadi, 2007). Menurut Mahsun (2006), kinerja adalah gambaran mengenai tingkat pencapaian pelaksanaan suatu kegiatan/ program/kebijakan dalam mewujudkan sasaran, tujuan, visi dan misi organisasi yang tertuang dalam strategic planing (perencanaan strategis) suatu organisasi. Istilah kinerja sendiri sering digunakan untuk menyebut prestasi atau tingkat keberhasilan individu maupun kelompok individu. Kinerja perusahaan adalah tingkat pencapaian hasil dalam rangka mewujudkan tujuan perusahaan (Simanjuntak, 2005). 


\section{Tata kelola Teknologi Informasi}

Keunggulan penerapan teknologi informasi adalah kecepatan, konsistensi, ketepatan, dan keandalan (Sutarman, 2009). Karena komputer memproses informasi secara konsisten, sistem TI dapat mengurangi salah saji dengan mengganti prosedur yang biasanya dilakukan secara manual dengan pengendalianpengendalian yang terprogram yang menerapkan fungsi saling mengawasi dan mengontrol untuk setiap transaksi yang diproses (Arens, et al., 2011).

Tata kelola TI sebagai tanggung jawab eksekutif dan dewan direksi terdiri dari kepemimpinan, struktur organisasi dan proses yang memastikan bahwa TI perusahaan menopang dan memperluas strategi dan tujuan organisasi (ITGI, 2005). Tata kelola TI merupakan landasan kerja yang mengukur dan memutuskan penggunaan dan pemanfaatan teknologi informasi dengan mempertimbangkan maksud, tujuan, dan sasaran bisnis perusahaan (Henderi dan Abas, 2008).

\section{Audit Kontinu}

Audit kontinu (continuous auditing) adalah metode apapun yang digunakan oleh auditor untuk melakukan kegiatan audit yang terkait secara lebih kontinu atau terus-menerus (IIA, 2005).

Audit kontinu adalah pengumpulan bukti audit dan indikator oleh auditor internal terhadap sistem teknologi informasi (TI), proses, transaksi, dan kontrol secara sering berulang, dan berkelanjutan. Ini mencakup proses penilaian risiko terus menerus manual, yaitu analisis yang umumnya secara kualitatif dikombinasikan berdasarkan proses analisis data (KPMG, 2012).

\section{Keselarasan Tujuan TI}

Tujuan teknologi informasi menurut Sutarman (2009) adalah untuk memecahkan masalah, membuka kreativitas, dan meningkatkan efektivitas dan efisiensi dalam melakukan pekerjaan. Tujuan TI didefinisikan secara umum sebagai pedoman perusahaan untuk mengidentifikasi perangkat bisnis yang penting dan tujuan teknologi informasi.

Keselarasan ditafsirkan sebagai keterkaitan yang direncanakan dan koheren (berhubungan) terus-menerus antara semua komponen perusahaan, personalia, dan sistem TI sehingga memberikan kontribusi terhadap performance perusahaan (Maes, et al., 2001). Henderson dan Venkatraman (1993) menyatakan keselarasan sebagai kecocokan internal dan fungsi integrasi startegi bisnis dan strategi TI dan penggabungan ini sangat penting untuk meningkatkan keuntungan kompetitif. Penyelarasan didefinisikan oleh Luftman dan Brier (1999) sebagai penerapan sistem teknologi infromasi di waktu dan cara yang tepat dan harmoni dengan strategistrategi, tujuan-tujuan, dan kebutuhankebutuhan bisnis. Boar (1994) misalnya, menyebutkan bahwa organisasi perlu membangun, menyelaraskan, dan mengembangkan keunggulan kompetitif melalui pemberdayaan sistem/teknologi informasi untuk menjawab tantangan kompetisi global.

\section{Kerangka Pemikiran \\ Pengaruh Tata Kelola TI Terhadap Kinerja Perusahaan \\ Dewasa ini manejemen} menghadapi meluapnya informasi yang tidak relevan (Boynton, et al., 2003). Anggota dewan komisaris, manejemen senior dan karyawan mengharapkan informasi yang lebih baik dan sesuai dengan kebutuhan organisasi. Menurut Boynton, et al (2003), informasi yang sesuai dengan yang dibutuhkan menjadikan informasi tersebut memiliki nilai tambah bagi perusahaan. Tata kelola terhadap TI berperan untuk membantu pihak-pihak dalam organisasi untuk mencapai peran optimal TI bagi organisasi.

Penerapan tata kelola TI secara baik pada berbagai aspek pelayanan dan kegiatan operasional bisnis perusahaan 
atau organisasi dilakukan dalam rangka meningkatkan efektivitas dan efisiensi organisasi dalam melaksanakan kegiatan operasional,dan mencapai sasaran dan tujuan yang telah ditetapkan (Henderi dan Padeli 2009). Menurut ITGI (2008), dengan tata kelola TI proses bisnis dapat dilaksanakan dengan lebih cepat dan lebih baik secara berkesinambungan untuk menunjang aktivitas utama perusahaan secara keseluruhan. Tata kelola TI yang dijalankan dengan menggunakan standar kualitas tinggi seperti standar kinerja dan keamanan TI menghasilkan informasi yang lebih terjaga, aman, tepat waktu, handal, terpercaya, dan dapat digunakan sesuai kebutuhan.

\section{Pengaruh Audit Kontinu Terhadap Kinerja Perusahaan}

Dengan meningkatnya tuntutan bisnis dan semakin tingginya lingkungan peraturan, auditor internal mencari pandangan yang lebih dalam pengendalian internal dan cara baik untuk mengurangi risiko serta memperluas cakupan audit semua dengan sumber daya audit internal yang terbatas (IIA, 2005). Auditor internal semakin mengakui manfaat dari audit kontinu yang melebihi audit tradisional atau audit berkala untuk mencapai tujuan tersebut dan memanfaatkan teknologi sebagai komponen penting.

Fokus audit kontinu tidak hanya pada kepatuhan dengan kontrol dan peraturan, tetapi peningkatan efisiensi operasi dalam organisasi. Audit kontinu juga harus memberikan kontribusi untuk peningkatan keseluruhan organisasi dengan mengidentifikasi dan menilai risiko dan memberikan informasi kepada manajemen dalam rangka untuk lebih merespon perubahan kondisi bisnis (IIA, 2005).

Jika diterapkan dengan benar, analisis data dan audit kontinu dapat membantu departemen internal auditor dalam menyederhanakan dan meningkatkan proses audit melalui peningkatan efisiensi operasional, mengurangi biaya, dan mendeteksi potensi kecurangan, kesalahan, dan penyalahgunaan lebih awal sambil menyediakan kualitas audit lebih tinggi. Hal tersebut juga makin menjadi cara bagi organisasi untuk menciptakan nilai (KPMG, 2012) Dari uraian diatas dapat ditarik kesimpulan bahwa audit kontinu berpengaruh terhadap kinerja perusahaan.

\section{Pengaruh Keselarasan Tujuan TI Terhadap Kinerja Perusahaan}

Prinsip keselarasan tujuan teknologi informasi menurut ITGI (2008), mengharuskan manajemen senior dalam perusahaan untuk tidak membiarkan terjadinya benturan dan ketidaksesuaian antara pelaksaan teknologi informasi terhadap tujuan perusahaan.

Menurut ITGI (2008), keselarasan tujuan TI dapat menjadi pendukung/ penggerak bisnis dengan adanya strategi yang yang saling terkait atau berhubungan satu sama lain. Prinsip keselarasan tujuan TI dengan tujuan bisnis mengupayakan kemampuan TI untuk merespon perubahan kebutuhan bisnis secara tangkas dan selaras dengan hukum dan peraturan yang berlaku. Keselarasan tujuan TI mengupayakan diperolehnya komitmen dan dukungan dari manajemen eksekutif. Melalui keselarasan tujuan TI, diupayakan keamanan (kerahasiaan, integritas, dan ketersediaan) terhadap informasi dan infrastruktur pengolahan serta adanya pertanggungjawaban dan perlindungan terhadap aset-aset TI. Proyek/kegiatan TI yang selaras dengan tujuan TI diupayakan berhasil dilaksanakan tepat waktu dan sesuai anggaran, juga memenuhi standar kualitas.

bahwa keselarasan mampu mengoptimalkan pemanfaatan TI dalam perusahaan dan mampu meningkatkan kinerja perusahaan sebagaimana hasil penelitian Almajali, et al (2011) yang menemukan bahwa keselarasan tujuan TI terhadap bisnis dapat membantu organisasi meningkatkan dampak positif TI terhadap 
keberhasilan organisasi. Hasil penelitian ini mendukung hasil penelitian yang dilakukan 0leh Cragg, et al (2002) yang menemukan bahwa perusahaan dengan keselarasan TI yang tinggi mencapai kinerja yang lebih baik daripada perusahaan dengan keselarasan TI yang rendah.

\section{Pengaruh Tata Kelola TI Terhadap Keselarasan Tujuan TI \\ Keselarasan strategis dalam} kegiatan organisasi sangat penting karena konsep strategis bisa memperhitungkan segala sesuatu yang akan dihadapi oleh tatakelola organisasi sebagaimana hasil penelitian yang dilakukan Marrone, et al. (2010). Keselarasan TI dan bisnis telah diidentifikasi sebagai sumber daya organisasi yang penting, memfasilitasi fleksibilitas TI dan fleksibilitas bisnis. Karena itu keselarasan strategis menekankan otoritas pada tata kelola TI yang baik, dan memastikan TI memberikan kontribusi secara efektif terhadap pencapaian tujuan strategis organisasi.

Pentingnya kerjasama antara bisnis dan TI untuk memaksimalkan investasi dalam teknologi sudah jelas. Teknologi informasi memainkan peran yang semakin meningkat dalam menentukan strategi perusahaan, aplikasi yang benar akan memfasilitasi organisasi menjadi lebih kompetitif dan menguntungkan. Keselarasan tujuan TI perusahaan adalah penting untuk memastikan TI yang digunakan layak/ tepat agar mampu/ memungkinkan untuk mendorong strategi bisnis (Luftman, 1999). Tata kelola TI yang disusun dengan baik dapat menyediakan kerangka tujuan untuk strategi TI, melakukan pengukuran dan penilaian tahunan, dan menguji keselarasannya. Perencanaan strategis TI dan keselarasan strategis yang efektif dapat dicapai jika tata kelola TI organisasi dilaksanakan, dikembangkan/ dibangun secara modern dengan memperhatikan aspek eksternal, melibatkan pihak eksternal, para stakeholder, direksi, komisaris, dan pihak lain. Dapat disimpulkan bahwa tata kelola TI berpengaruh terhadap keselarasan tujuan TI.

\section{Pengaruh Tata Kelola TI Terhadap Audit Kontinu}

Menurut Boynton, et al (2003), kita saat ini sedang berada ditengah revolusi teknologi informasi yang hasilnya sulit diramalkan namun memiliki kecendrungan implikasi yang baik bagi organisasi. Implikasi dimaksud antara lain lebih mudah untuk menarik, memproduksi melacak, dan menganalisis informasi. Banyak aspek kunci dari pengendalian internal menggunakan TI dan penggunaan TI telah mempermudah pengambilan keputusan untuk melacak informasi (Boynton, et al., 2003). Implikasi lainnya, keamanan teknologi diyakini akan terus meningkat dengan skema proteksi database yang membatasi akses hanya pada orang-orang yang berwenang.

Audit kontinu menurut IIA (2005) dilaksanakan pada perusahaan yang menggunakan teknologi informasi dalam membantu proses bisnis perusahaan. Audit kontinu sebagai metode yang digunakan untuk melakukan kontrol dan penilaian risiko otomatis secara lebih sering membutuhkan teknologi yang merupakan kunci yang memungkinkan pendekatan semacam itu. Hal ini mengingat audit kontinu mengubah paradigma audit dari review periodik terhadap sampel transaksi menjadi pengujian audit (audit testing) terus-menerus (berkelanjutan) terhadap 100 persen transaksi dan menjadi bagian integral dari audit modern pada berbagai tingkatan.

Adanya tatakelola TI yang merupakan landasan kerja yang mengukur dan memutuskan penggunaan dan pemanfaatan teknologi informasi dengan mempertimbangkan maksud, tujuan, dan sasaran bisnis perusahaan, diindikasikan dapat mempengaruhi audit kontinu agar lebih terarah, efisien dan efektif. 
Pengelolaan data menggunakan perangkat bantu TI yang canggih dengan otomasi data yang maksimal membantu kegiatan audit kontinu dalam menelusuri jejak transaksi, memitigasi resiko, dan membantu manajemen dalam menyediakan informasi relevan untuk pengambilan keputusan. Dapat disimpulkan bahwa tatakelola TI berpengaruh terhadap audit kontinu.

\section{Pengaruh Keselarasan Tujuan Teknologi Informasi Terhadap Audit Kontinu}

Sebuah pendekatan audit kontinu memungkinkan auditor internal untuk memahami titik kritis kontrol (critical control point), aturan (rules), dan pengecualian (exception) (IIA, 2005). Secara otomatis, auditor internal mampu melakukan kontrol dan penilaian risiko secara real time atau dekat real time, dapat menganalisis sistem bisnis utama bagi anomali pada tingkat transaksi dan indikator data-driven, kekurangan kontrol dan risiko yang muncul (IIA, 2005).

Keselarasan tujuan TI sebagai penerapan sistem teknologi infromasi di waktu dan cara yang tepat dan harmoni dengan strategi- strategi, tujuan-tujuan, dan kebutuhan-kebutuhan bisnis mampu membangun, menyelaraskan, dan mengembangkan keunggulan kompetitif melalui pemberdayaan sistem/teknologi informasi untuk menjawab tantangan kompetisi global. Keselarasan strategis memiliki fokus dalam memastikan hubungan antara bisnis dan rencana TI, menentukan, merawat, dan memastikan pengunaan TI dapat mendukung pencapaian tujuan dan menjamin kelangsungan organisasi. Keselarasan strategis yang baik, tepat, kredibilitas dan relevan dibangun dengan memperhatikan prioritas TI, anggaran, isu-isu bisnis yang paling hangat dan menjadi perhatian organisasi dan pelanggan, melibatkan para direksi, CEO, semua bagian di organisasi, dan pelanggan bisnis untuk memahami apa yang penting. Dari uraian ini dapat diidentifikasikan bahwa keselarasan tujuan TI juga berpengaruh terhadap audit kontinu.

Dari uraian di atas, maka disusun model penelitian sebagai berikut:

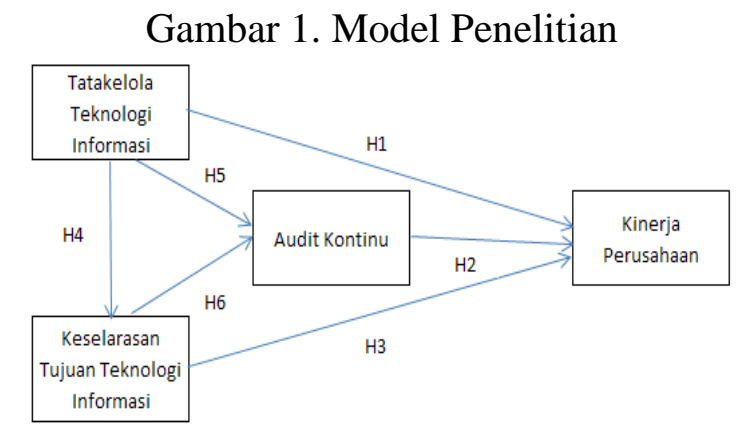

\section{Hipotesis}

Sugiyono (2009) menyatakan hipotesis merupakan jawaban sementara terhadap rumusan masalah penelitian, di mana rumusan masalah telah dinyatakan dalam bentuk kalimat pertanyaan. Dikatakan sementara karena jawaban yang diberikan baru didasarkan pada teori yang relevan, belum didasarkan fakta-fakta empiris. Peneliti mengajukan hipotesis sebagai berikut:

$\mathrm{H}_{1}$ : Tatakelola TI berpengaruh terhadap kinerja perusahaan.

$\mathrm{H}_{2}$ : Audit kontinu berpengaruh terhadap kinerja perusahaan

$\mathrm{H}_{3}$ : Keselarasan tujuan TI berpengaruh terhadap kinerja perusahaan.

$\mathrm{H}_{4}$ : Tatakelola TI berpengaruh terhadap keselarasan tujuan TI.

$\mathrm{H}_{5}$ : Tatakelola TI berpengaruh terhadap audit kontinu.

$\mathrm{H}_{6}$ : Keselarasan tujuan TI berpengaruh terhadap audit kontinu

\section{Metode Penelitian \\ Jenis dan Sumber Data}

Penelitian ini menggunakan jenis data primer. Data primer adalah data yang diperoleh atau dikumpulkan oleh peneliti secara langsung dari sumber datanya (sumber primer). Menurut Sugiyono (2012) sumber primer adalah sumber data yang langsung memberikan data kepada pengumpul data. 


\section{Populasi dan Sampel}

Populasi dalam penelitian ini adalah para manejer pada kelompok perusahaan perkebunan PT. Astra Agro Lestari, Tbk di Riau. Penarikan sampel menggunakan cara purposive sampling dengan menetapkan ciri yang sesuai dengan tujuan. Peneliti hanya mengambil manejer pada level tertentu yaitu level manejer puncak sebagai pengambil keputusan dalam struktur utama organisasi perusahaan.

\section{Teknik Pengumpulan Data}

Peneliti melakukan pengumpulan data dari responden melalui kuesioner yang dikirim ke email resmi masingmasing manejer yang dimaksud pada kelompok perusahaan perkebunan PT. Astra Agro Lestari, Tbk di Riau.

\section{Variabel Penelitian dan Definisi Operasional \\ Kinerja Perusahaan}

Persepsi kinerja perusahaan dalam penelitian ini diukur dengan menggunakan balance scorecard pada perspektif keuangan, perspektif proses bisnis internal, dan perspektif pertumbuhan dan pembelajaran. Instrumen yang digunakan untuk mengukur kinerja berdasarkan prioritised list of business goals for the manufacturing and pharmaceuticals sector (ITGI, 2008).

\section{Tata Kelola teknologi Informasi}

Persepsi terhadap variabel pengaruh tata kelola TI diukur dengan mengacu pada standar COBIT (Control Objective for Information and related Technology) dari ITGI dengan domaindomain sebagai berikut: Plan and Organize, Acquisition and Implementation, Deliver and Support, Monitoring and Evaluate

\section{Audit Kontinu}

Variabel dalam penelitian ini diukur dengan continuous risk assurance, dan continuous risk assessment dan implementing yang diadopsi dari GTAG on continuos auditing (IIA, 2005).

\section{Keselarasan Tujuan Teknologi Informasi}

Variabel keselarasan tujuan TI diukur dengan Prioritised list of IT Goals for the Manufacturing and Pharmaceuticals sector yang dikeluarkan oleh IT Governance Institute dengan keselarasan pada sisi corporate dan operational.

\section{Deskripsi Objek Penelitian}

Objek dalam penelitian ini adalah kelompok perusahaan perkebunan PT. Astra Agro Lestari, Tbk di Riau. PT. Astra Agro Lestari, Tbk adalah anak perusahaan dari PT. Astra International, Tbk yang bergerak di bidang agribisnis, khususnya dalam pengelolaan perkebunan kelapa sawit dan produksi minyak sawit untuk memenuhi kebutuhan domestik dan ekspor (AAL, 2015).

Teknologi informasi mempunyai peranan yang sangat penting dalam mendukung bisnis perkebunan, apalagi banyak areal perkebunan kelompok perusahaan perkebunan PT. Astra Agro Lestari, Tbk (selanjutnya disebut perseroan) berada di daerah terpencil (AAL, 2015).

Perseroan menerapkan solusi teknologi informasi Enterprise Resources Planning (ERP). Sistem ERP Perseroan menyediakan data terkini dan terintegrasi dari proses bisnis keuangan, pembelian dan distribusi di seluruh unit bisnis., Human Resources Integrated System (HRIS), otomasi, dan digital.

Populasi dalam penelitian ini adalah pihak manajemen kelompok perusahaan perkebunan PT. Astra Agro Lestari, Tbk di Riau. Sampel penelitian diambil dari manajer level puncak yang berada pada struktur utama kelompok perusahaan tersebut dengan jumlah 60 sampel.

Berikut kelompok perusahaan perkebunan PT. Astra Agro Lestari, Tbk di Riau dimaksud: 
Tabel 1

Kelompok Perusahaan Perkebunan

PT. Astra Agro Lestari, Tbk di Riau.

\begin{tabular}{|c|l|l|}
\hline No & \multicolumn{1}{|c|}{ Nama Perusahaan } & \multicolumn{1}{c|}{ Lokasi } \\
\hline 1 & PT. Tunggal Perkasa Plantation & $\begin{array}{l}\text { Kabupaten Indragiri Hulu, Provinsi } \\
\text { Riau }\end{array}$ \\
\hline 2 & PT. Ekadura Indonesia & $\begin{array}{l}\text { Kabupaten Pelalawan, } \\
\text { Provinsi Riau }\end{array}$ \\
\hline 3 & PT. Sari Lembah Subur-1 & $\begin{array}{l}\text { Kabupaten Pelalawan, } \\
\text { Provinsi Riau }\end{array}$ \\
\hline 4 & PT. Sari Lembah Subur-2 & $\begin{array}{l}\text { Kabupaten Pelalawan, } \\
\text { Provinsi Riau }\end{array}$ \\
\hline 5 & PT. Sawit Asahan Indah & $\begin{array}{l}\text { Kabupaten Rokan Hulu, } \\
\text { Provinsi Riau }\end{array}$ \\
\hline 6 & PT. Kimia Tirta Utama & $\begin{array}{l}\text { Kabupaten Siak, } \\
\text { Provinsi Riau }\end{array}$ \\
\hline
\end{tabular}

Dari 60 kuesioner yang dikirim kepada manejer level atas kelompok perusahaan dimaksud, kuesioner yang dikembalikan responden berjumlah 40 . Kuesioner yang kembali diterima dalam keadaan lengkap dalam pengisian sehingga dapat menjadi data untuk penelitian ini. Jumlah tersebut memadai syarat kecukupan sampel pengolahan data dengan PLS, yaitu minimal 30 sampel.

\section{Hasil Analisis Data Menggunakan Smart PLS Pengujian Hipotesis}

Tabel 2. Path Coefficients (Mean, STDEV, T-Values)

\begin{tabular}{|l|c|c|c|c|r|}
\hline & $\begin{array}{c}\text { Original } \\
\text { Sample }(O)\end{array}$ & $\begin{array}{c}\text { Sample } \\
\text { Mean }(M)\end{array}$ & $\begin{array}{c}\text { Standard } \\
\text { Deviation } \\
(\text { STDEV })\end{array}$ & $\begin{array}{c}\text { Standard } \\
\text { Error } \\
(\text { STERR })\end{array}$ & $\begin{array}{c}\text { T Statistics } \\
(\mid \text { OSTERR })\end{array}$ \\
\hline AK -> KIN & 0.209265 & 0.220932 & 0.103105 & 0.103105 & 2.029632 \\
\hline KTI -> AK & 0.162892 & 0.171412 & 0.111262 & 0.111262 & 1.464039 \\
\hline KTI -> KIN & 0.978212 & 1.002970 & 0.114623 & 0.114623 & 8.534163 \\
\hline TTI -> AK & 0.564070 & 0.554981 & 0.106113 & 0.106113 & 5.315737 \\
\hline TTI -> KIN & -0.756068 & -0.786292 & 0.147167 & 0.147167 & 5.137476 \\
\hline TTI -> KTI & 0.791503 & 0.801101 & 0.054138 & 0.054138 & 14.620166 \\
\hline
\end{tabular}

Sumber: output smartPLS (2015)

Tabel 3. Hasil Pengujian Hipotesis

\begin{tabular}{|c|l|c|}
\hline & \multicolumn{1}{|c|}{ HIPOTESIS } & KETERANGAN \\
\hline H1 & $\begin{array}{l}\text { Tatakelola TI berpengaruh terhadap kinerja } \\
\text { perusahaan }\end{array}$ & Diterima \\
\hline
\end{tabular}




\begin{tabular}{|c|l|c|} 
H2 & $\begin{array}{l}\text { Audit kontinu berpengaruh terhadap kinerja } \\
\text { perusahaan }\end{array}$ & Diterima \\
\hline H3 & $\begin{array}{l}\text { Keselarasan tujuan teknologi TI berpengaruh } \\
\text { terhadap kinerja perusahaan }\end{array}$ & Diterima \\
\hline H4 & $\begin{array}{l}\text { Tatakelola TI berpengaruh terhadap keselarasan } \\
\text { tujuan TI }\end{array}$ & Diterima \\
\hline H5 & $\begin{array}{l}\text { Tatakelola TI berpengaruh terhadap audit } \\
\text { kontinu }\end{array}$ & Diterima \\
\hline H6 & $\begin{array}{l}\text { Keselarasan tujuan TI berpengaruh terhadap } \\
\text { audit kontinu }\end{array}$ & Ditolak \\
\hline
\end{tabular}

Penjelasan Hasil Pengujian Hipotesis

Hasil Pengaruh Tata Kelola TI Terhadap Kinerja Perusahaan

Hubungan antara tata kelola TI dengan kinerja perusahaan adalah signifikan dengan T-statistik sebesar 5.137476 yang lebih besar dari T-tabel sebesar 1,96. Dengan demikian hipotesis H1 dalam penelitian ini yang menyatakan bahwa tata kelola teknologi informasi berpengaruh terhadap kinerja perusahaan diterima. Temuan ini menyimpulkan bahwa tata kelola TI berperan penting dalam pencapaian kinerja perusahaan. Hasil ini konsisten dengan penelitian sebelumnya dari Wu (2015), Metagroup (2005), Weill dan Ross (2004) yang menyatakan bahwa tata kelola TI berpengaruh signifikan terhadap kinerja perusahaan.

Penerapan tata kelola TI secara baik pada berbagai aspek pelayanan dan kegiatan operasional bisnis perusahaan meningkatkan efektivitas dan efisiensi organisasi (Henderi dan Padeli 2009) dan proses bisnis dapat dilaksanakan dengan lebih cepat dan lebih baik secara berkesinambungan untuk menunjang aktivitas utama perusahaan secara keseluruhan (ITGI, 2008).

\section{Hasil Pengaruh Audit Kontinu Terhadap Kinerja Perusahaan}

Hubungan antara audit kontinu dan kinerja perusahaan adalah signifikan dengan T-statistik sebesar 2.029632 yang lebih besar dari t-tabel sebesar 1.96 . Dengan demikian hipotesis H2 dalam penelitian ini yang menyatakan bahwa audit kontinu berpengaruh terhadap kinerja perusahaan diterima. Temuan ini mengindikasikan bahwa audit kontinu penting dilakukan dalam upaya meningkatkan kinerja perusahaan.

Temuan ini mendukung hasil penelitian yang dilakukan Warren, et al. (2003) dan Vasarhelyi (2013), yang menemukan bahwa audit kontinu membantu auditor internal dan meningkatkan kepercayaan investor organisasi, tanggap terhadap Sarbaney_Oxlay Act of 2002, bekerja dengan sistem TI yang kompleks dan meningkatkan tata kelola perusahaan.

Analisis data dan audit kontinu dapat membantu departemen internal auditor dalam menyederhanakan dan meningkatkan proses audit melalui peningkatan efisiensi operasional, mengurangi biaya, dan mendeteksi potensi kecurangan, kesalahan, dan penyalahgunaan lebih awal dan secara bersamaan menyediakan kualitas audit lebih tinggi yang makin menjadi cara bagi organisasi untuk menciptakan nilai (KPMG, 2012)

\section{Hasil Pengaruh Keselarasan Tujuan Teknologi Informasi Terhadap Kinerja Perusahaan}

Hubungan antara keselarasan tujuan TI dengan kinerja perusahaan adalah signifikan dengan T-statistik sebesar 8.534163 yang lebih besar dari ttabel sebesar 1.96. Dengan demikian hipotesis $\mathrm{H} 3$ dalam penelitian ini yang 
menyatakan bahwa keselarasan tujuan TI berpengaruh terhadap kinerja perusahaan diterima. Dari hasil ini dapat diartikan bahwa keselarasan tujuan TI berperan penting dalam pencapaian kinerja perusahaan.

Temuan ini mendukung penelitian yang dilakukan oleh Cragg, et al. (2002) dan Almajali, et al (2011) yang menemukan bahwa perusahaan dengan keselarasan TI tinggi mencapai kinerja organisasi yang lebih baik daripada perusahaan dengan keselarasan TI rendah dan bahwa keselarasan strategis memiliki pengaruh yang signifikan terhadap keunggulan kompetitif yang berkelanjutan.

Manejemen senior menurut ITGI (2008) harus mengupayakan kesesuaian pelaksanaan TI terhadap tujuan perusahaan dan mencegah benturan keduanya dengan adanya strategi yang saling terkait/selaras antara tujuan TI dan tujuan bisnis agar mampu memenuhi kebutuhan bisnis dan merespon perubahan kebutuhan bisnis secara tangkas dan selaras dengan hukum dan peraturan yang berlaku.

\section{Hasil Pengaruh Tata Kelola Teknologi Informasi Terhadap Keselarasan Tujuan Teknologi Informasi}

Hubungan antara teknologi

informasi terhadap keselarasan tujuan TI adalah signifikan dengan T-statistik sebesar 14.620166 yang lebih besar dari ttabel sebesar 1.96. Dengan demikian hipotesis $\mathrm{H} 4$ dalam penelitian ini yang menyatakan bahwa tatakelola TI berpengaruh terhadap keselarasan tujuan TI diterima. Temuan ini mengindikasikan bahwa tatakelola TI berperan penting dalam pencapaian keselarasan tujuan TI.

Tata kelola TI yang disusun dengan baik dapat menyediakan kerangka tujuan untuk strategi TI dan keselarasannya. Perencanaan strategis TI dan keselarasan strategis yang efektif dapat dicapai jika tata kelola TI organisasi dilaksanakan, dikembangkan/ dibangun secara modern dengan turut memperhatikan aspek eksternal, melibatkan pihak eksternal, para stakeholder, direksi, komisaris, dan pihak lain.

\section{Hasil Pengaruh Tata Kelola Teknologi Informasi Terhadap Audit Kontinu}

Hubungan antara teknologi informasi terhadap keselarasan tujuan TI adalah signifikan dengan T-statistik sebesar 5.315737 yang lebih besar dari ttabel sebesar 1.96. Dengan demikian hipotesis H5 dalam penelitian ini yang menyatakan bahwa tatkelola TI berpengaruh terhadap audit kontinu diterima. Temuan ini menunjukkan bahwa tatakelola TI merupakan pendukung terlaksananya audit kontinu.

Kemajuan teknologi komputer memberikan pengaruh yang sangat besar di bidang akuntansi, termasuk auditing. Menurut Kogan dan Vasarhelyi (1999) dalam Ariston dan Jessica (2006), audit berbasis komputer mulai menjadi suatu kebutuhan, yang berdampak pada peningkatan efisiensi audit (Kogan dan Vasarhelyi., 1999).

Audit kontinu sangat bergantung pada teknologi (Bibi, 2010). Oleh karena itu perencanaan TI yang memadai untuk mengarahkan organisasi secara keseluruhan pada misi aktivitas utama perusahaan, serta kualitas TI yang kuat dan handal akan membantu terlaksananya audit kontinu dalam perusahan secara terarah. Teknologi informasi memberikan jaminan yang independen dan diaudit untuk memastikan sistem TI bekerja dengan netral memberikan suatu keyakinan bagi auditor internal terhadap hasil audit kontinu.

\section{Hasil Pengaruh Keselarasan Tujuan Teknologi Informasi Terhadap Audit Kontinu}

Hubungan antara teknologi informasi terhadap keselarasan tujuan TI adalah signifikan dengan T-statistik sebesar 1.464039 yang kurang dari dari ttabel sebesar 1.96. Maka dapat dikatakan bahwa hipotesis H6 ditolak yaitu keselarasan tujuan TI tidak berpengaruh 
signifikan terhadap audit kontinu. Dari temuan ini dapat disimpulkan bahwa keselarasan tujuan TI tidak menjadi faktor penentu dalam terlaksananya audit kontinu.

Keselarasan strategis memiliki fokus dalam memastikan hubungan antara bisnis dan rencana TI, menentukan, merawat, dan memastikan pengunaan TI dapat mendukung pencapaian tujuan dan menjamin kelangsungan organisasi namun tidak berpengaruh signifikan terhadap pelaksanaan audit kontinu.

\section{PENUTUP}

Dari hasil pengujian dengan PLS dan berdasarkan pembahasan pada bab 4 , penelitian ini menemukan hal-hal sebagai berikut:

1. Tatakelola TI berpengaruh signifikan terhadap kinerja perusahaan. Dari hasil ini dapat diartikan bahwa tatakelola TI berperan penting dalam pencapaian kinerja perusahaan.

2. Audit kontinu berpengaruh signifikan terhadap kinerja perusahaan. Dapat diartikan bahwa audit kontinu penting dilaksanakan untuk mencapai kinerja perusahaan yang baik.

3. Keselarasan tujuan TI berpengaruh signifikan terhadap kinerja perusahaan. Dari hasil ini dapat diartikan bahwa keselarasan tujuan TI berperan penting dalam pencapaian kinerja perusahaan.

4. Tatakelola TI berpengaruh signifikan terhadap keselarasan tujuan TI. Dari hasil ini dapat diartikan bahwa tatakelola TI berperan penting dalam pencapaian keselarasan tujuan TI.

5. Tatakelola TI berpengaruh signifikan terhadap audit kontinu. Dari hasil ini dapat diartikan bahwa tatakelola TI merupakan bagian penting untuk terlaksananya audit kontinu.

6. Keselarasan tujuan TI tidak berpengaruh signifikan terhadap audit kontinu, artinya keselarasan tujuan TI tidak menjadi faktor penentu dalam terlaksananya audit kontinu.

\section{Saran}

Bagi peneliti selanjutnya yang akan melakukan penelitian sejenis ataupun berhubungan dengan penelitian ini, maka saran yang dapat penulis berikan adalah sebagai berikut:

1. Penelitian sejenis pada populasi yang lebih luas dapat dilakukan, demikian juga penelitian pada populasi perusahaan jenis lainnya.

2. Penelitian berikutnya dapat menambahkan variabel lain yang masih berkaitan dengan teknologi informasi seperti Continuous Monitoring (CM) dan menguji pengaruhnya terhadap kinerja.

\section{DAFTAR PUSTAKA}

AAL., 2015, http://www.astra-agro.co.id, Diakses April 2015.

Arens, Alvin A., Randal J. Elder, and Mark S. Beasley., 2008, Auditing dan jasa Assurance, Penerjemah Hermawan Wibowo, Erlangga, Jakarta ,2011, Jasa Audit dan Assurance. Penerjemah Desti Fitriani, Penerbit Salemba Empat, Jakarta.

Boynton, William, Raymond Johnson, and Walter Kell, 2003, Modern Auditing, Edisi Ketujuh, Jilid 1, Erlanggga, Jakarta.

Deloitte., 2010, Continuous Monitoring and Continuous Auditing From Idea to Implementation, Deloitte Development LLC.

Henderi dan Padeli., 2009, IT Governance_Support for Governance. CCIT Journal, 142150.

Hunton, J. E., \& Bagranoff, N. A., 2004, Information Technology Auditing. Wiley.

Institute of Internal Auditor., 2005, Global Technology Auditing Guide 3. Continuous Auditing: Implications for Assurance, Monitoring, and Risk Assessment

ISACA, 2007, COBIT 4.1. Framework for IT Governance and Control. 
http://www.isaca.org/KnowledgeCenter/cobit/Pages/Overview.aspx Diakses Juli 2014.

IT Governance Institute., 2008, Understanding How Business Goals Drive IT Goal, ITGI.

Jensen, Michael C., and William $\mathrm{H}$. Meckling., 1976, Theory of the Firm: Managerial Behavior, Agency Costs and Ownership Structure. Journal of Financial Economics 3.4 (1976): 305-360.

KPMG, 2012, Leveraging Data Analytics and Continuous Auditing Processes for Improved Audit Planning, Effectiveness, and Efficiency.

Martusa, Riki., Verani Carolina, dan Meythi., 2011, Continuous Auditing: Strategi Pengauditan Berbasis Teknologi Informasi.

Mulyadi., 2007, Sistem Perencanaan dan Pengendalian Manajemen, Salemba Empat Jakarta.

Sembiring, Satya Wisada., 2013, Evaluasi Penerapan Teknologi Informasi Menggunakan Model COBIT Framework 4.1 (Studi Kasus: PT. Prudential Indonesia, Tesis Magister Teknik Informatika Universitas Atmajaya, Yogakarta.

Sugiyono., 2009, Metode Penelitian Bisnis, Alfabeta, Bandung. , 2012, Metode Penelitian Bisnis, Alfabeta, Bandung.

Sutarman., 2009, Pengantar Teknologi Informasi, Bumi Aksara, Jakarta.

Tallon, Paul P., Kenneth L. Kraemer, and Vijay Gurbaxani. 2000. Executives' Perceptions Of The Business Value Of Information Technology: A Process-Oriented Approach. Journal Of Management Information Systems : 145-173.

Tugas, F., 2010, Assessing The Level Of Information Technology (It)
Processes Performance And
Capability Maturity In The
Philippine Food, Beverage, And
Tobacco (Fbt) Industry Using The
Cobit Framework, Academy of
Information and Management Sciences Journal , 13, 45.

Turban, Efraim \& Linda Volonino., 2010, Information Technology for Management: Transforming Organization in the Digital Economy, $7^{\text {th }}$ edition, John Wiley \& Sons, Inc.

Ulysses, John Frederick., 2013, Pengaruh Tata Kelola Teknologi Informasi dalam Keselarasan Proses Bisnis Perusahaan, Magister Teknik Universitas Atmajaya, Yogyakarta.

Weill, Peter, and Jeanne W. Ross., 2004, IT Governance: How Top Performers Manage IT Decision Rights For Superior Results, Harvard Business Press 
